\title{
Mesmo sem saber por quê
}

\section{Marta Isaacson}

Por que ensinar teatro na era da comunicação digital, da Internet? Por que ensinar teatro quando fazer teatro parece uma tarefa quase impossível em uma sociedade fortemente arraigada ao desenvolvimento científico? Por que ensinar teatro, se o processo de criação artística guarda sempre uma parcela de desconhecido, um espaço à ação do acaso? Para todas estas questões, talvez haja uma única resposta: amamos ensinar aquilo que amamos. Mas por que amamos o teatro? Porque sentimos nele um poder. Poder de transformação? Transgressão?... Pouco importa. Não sabemos muito bem qualificar e somos menos ainda capazes de quantificar. $O$ certo é que percebemos nele um poder que concretiza nosso desejo de liberdade.

Desta forma, em uma caminhada de incertezas, temos a pretensão de ensinar, por vezes, com o olhar voltado ao processo de criação, por outras vezes, na perspectiva da recepção; em certas oportunidades, realizando uma abordagem histórica, em outras, um estudo literário... Assim, ensinamos e formamos profissionais para uma arte efêmera como a vida, dando continuidade ao compromisso dos mestres com os quais aprendemos a amar o teatro, de tal forma que ele se tornou inseparável de nossas vidas.

Tão impossível é resgatar o poder da experiência teatral quanto resgatar os fatos da vida. Ainda assim, tenho a pretensão de falar de teatro e vida, lembrando que a Universidade Federal do Rio Grande do Sul foi uma das primeiras instituições brasileiras de ensino superior a ofertar, em 1958, o ensino do teatro. Iniciativa realizada antes mesmo do Conselho Federal de Educação definir o ensino da arte dramática como área de formação superior. Nunca é demais ressaltar o importante papel do primeiro corpo docente do então Centro de Arte Dramática / UFRGS no desenvolvimento da prática e na multiplicação do ensino do teatro em Porto Alegre e no interior do Rio Grande do Sul. Não só formando atores e diretores, mas dividindo suas atividades de ensino com o fazer teatral quotidiano, os professores colaboraram durante as 
décadas de sessenta e setenta de forma efetiva para a qualificação da produção em artes cênicas na região sul.

A inserção das artes na academia, mais do que uma conquista, ela foi início de nova luta, agora em busca de sua legitimidade dentro da universidade, espaço social extremamente resistente às diferenças, por mais contraditório que isto possa parecer. E nesta luta, até hoje não totalmente vencida, pelo fortalecimento do ensino superior da arte no Brasil, se seguiu a urgência de capacitação acadêmica de seus agentes formadores. Conscientes do significado desta demanda e motivados pelo desenvolvimento do ensino do teatro, muitos professores do Departamento de Arte Dramática (DAD) da UFRGS investiram, no início dos anos oitenta, em capacitação em cursos de mestrado, realizados principalmente nos Estados Unidos. Em um momento, onde a informação não estava ainda globalizada como hoje, a experiência dos docentes em instituições estrangeiras contribuiu de forma decisiva na ampliação dos referencias teóricos e técnico-artísticos do ensino do teatro dispensado no sul do país.

Desde o final da década de oitenta em Porto Alegre, assim como em outras grandes cidades do Brasil, multiplicaram-se as ofertas de formação de atores e diretores, desde workshops até cursos mais longos, desde iniciativas consistentes até as menos consistentes. Ainda que o exercício profissional em teatro nunca tenha exigido formação acadêmica, esta grande oferta de alternativas de aprendizado desafia a Universidade a especificar o seu papel, a marcar nitidamente a diferença de sua ação.

Lamentavelmente, para reagir à proliferação de cursos livres em teatro, algumas instituições particulares de ensino superior passaram, recentemente, a oferecer formação de atores dentro da modalidade de cursos superiores de tecnologia com duração de dois anos. No momento em que a formação do licenciado em artes se otimiza, graças à extinção da Educação Artística promovida pela nova legislação educacional, a formação dos profissionais da cena se transforma em cursos superiores curtos (e com o acesso garantido à pós-graduação strictu sensu!). Por mais absurda que filosoficamente a idéia se 
mostre, a fragilidade da legislação profissional permite sim que se associe 0 ator ao tecnólogo.

Felizmente, os professores do ensino superior público ainda não se viram enquadrados em tamanho paradoxo, pois das poucas prerrogativas que possuem está aquela de participar da gestão acadêmica. Assim, desde a década de oitenta, a universidade pública marca seu diferencial formativo na área das artes cênicas, investindo na articulação entre ensino e pesquisa. Passa a desenvolver com propriedade investigações tanto teóricas quanto práticas e amplia os patamares de formação dos profissionais das artes cênicas através da implantação de cursos de pós-graduação.

Sintonizados com o esforço de colegas de outras instituições superiores e na continuidade da luta de seus mestres, os professores do Departamento de Arte Dramática investiram nos últimos dez anos no desenvolvimento da pesquisa e da capacitação dos docentes em nível de doutorado. A este esforço se somaram, em 2000, o lançamento do primeiro número da Revista Cena e a primeira edição do Curso de Especialização Teoria do Teatro: Cena Contemporânea. Duas atividades com início marcado no dia 19 de abril por uma palestra do saudoso Renato Cohen, com suas idéias criativas e performáticas. Ao lado de docentes do DAD, Clóvis Massa, Flávio Mainieri, Inês Marocco, Irion Nolasco, João Pedro Gil, Marta Isaacsson, Mirna Spritzer, Sérgio Silva, Suzane Weber e Vera Bertoni, o Curso de Especialização, em suas três edições, pôde contar com a preciosa colaboração dos professores André Carreira, Edélcio Mostaço, Eliane Lisboa, Graça Nunes, José Augusto Avancini e Luiz Paulo Vasconcellos. Foi com enorme satisfação que vimos o retorno à "casa" de egressos de diferentes turmas do DAD e a chegada de profissionais oriundos de outros cursos e de outras instituições do país.

Encerrada a terceira edição do Curso de Especialização, em agosto de 2005, um pequeno grupo de professores 1 tomou a iniciativa de elaborar o projeto para implantação do curso de mestrado em artes cênicas. $O$ trabalho esteve pautado por uma troca construtiva, uma solidariedade rara no âmbito da universidade, despertada pela motivação de todos. Fundamentais foram os conselhos do Professor Sérgio Farias2, vindo a Porto 
Alegre especialmente para assessorar o grupo na formatação do projeto.

Neste ano de 2006, diante da aprovação pela CAPES/MEC para implantação do Programa de Pós-Graduação em Artes Cênicas / UFRGS, nada mais oportuno que o lançamento deste número da Revista Cena, reunindo estudos monográficos de alguns egressos do Curso de Especialização, parceiros da última etapa desta longa caminhada de cinqüenta anos de consolidação do ensino do teatro na Universidade Federal do Rio Grande do Sul. $E$ aos novos desafios que se abrem nesta virada de página, responderemos movidos pelo poder que o teatro nos desperta, mesmo se não saibamos ainda responder por quê.

\section{O que é felicidade sobre a terra? A conquista do saber, o processo de conhecimento. Tomemos consciência da arte para compreender a natureza, 0 sentido da vida. Não há felicidade maior. \\ Constantin Stanislavski}

\section{NOTAS:}

1 Aliados a mim, Marta Isaacsoon, estavam inicialmente Inês Marocco, João Pedro Gil e Silvia Balestreri. Posteriormente o grupo seampliou com as presenças de Clóvis Massa, Mirna Spritzer e Ubiratan Oliveira.
2 Coordenador do Programa de PósGraduação em Artes Cênicas da Universidade Federal da Bahia. 